Available online at GSC Online Press Directory

GSC Biological and Pharmaceutical Sciences

e-ISSN: 2581-3250, CODEN (USA): GBPSC2

Journal homepage: https://www.gsconlinepress.com/journals/gscbps

(RESEARCH ARTICLE)

\title{
Effect of Picralina nitida on the glycemia and intestinal absorption of glucose in rat
}

\author{
Placide Ehoue Adjoumani, Arsene Mea *, Parfait Kahou Bi Gohi, Jean Severin Irie Bi, Joseph Nguessan Koffi \\ and Jean Claude Abo Kouakou
}

\author{
Laboratory of Animal Physiology, Phytothérapy and Pharmacology; Felix Houphouët Boigny University, Abidjan, Côte \\ d'Ivoire.
}

Publication history: Received on 16 November 2018; revised on 19 December 2018; accepted on 24 December 2018

Article DOI: https://doi.org/10.30574/gscbps.2018.5.3.0137

\begin{abstract}
Oral administration of the aqueous fruit extract of Picralina nitida (AEPn) at the respective doses of 300, 400 and 500 $\mathrm{mg} / \mathrm{kg} \mathrm{BW}$ induces hypoglycemia on the blood glucose levels of normoglycemic rats. AEPn at dose of $300 \mathrm{mg} / \mathrm{kg}$ BW did not result in a significant (ns: P>0.05) decrease in blood glucose levels in treated rats (less of 5.49\%). AEPn at doses of 400 and $500 \mathrm{mg} / \mathrm{kg}$ BW produced significant decreases in blood glucose levels in treated rats. These hypoglycemia increases with time. Thus AEPn at the dose of $400 \mathrm{mg} / \mathrm{kg} \mathrm{BW}$ lowered blood glucose significantly decrease of $13.18 \%$ $\left.{ }^{* *} \mathrm{P}<0.01\right)$. And dose of $500 \mathrm{mg} / \mathrm{kg}$ BW results in a greater decrease, of $21.97 \%\left({ }^{* *} \mathrm{P}<0.01\right)$. Administration by gavage of anhydrous glucose $4 \mathrm{~g} / \mathrm{kg} \mathrm{BW}$ to rats causes hyperglycemia. This induced hyperglycemia is significantly reduced $\left({ }^{* *} \mathrm{P}<0.01\right)$ by AEPn in pretreated and post-treated rats. The AEPn reduction at $500 \mathrm{mg} / \mathrm{kg}$ BW of the glucose-induced hyperglycemia is identical to that of glibenclamide at $10^{-2} \mathrm{mg} / \mathrm{kg} \mathrm{BW}\left({ }^{* *} \mathrm{P}<0.01\right)$. Thus, like glibenclamide, AEPn has antihyperglycemic effects. The hypoglycemic and antihyperglycemic effects of AEPn, observed in vivo, can be attributed to the presence in this extract of polyphenols, flavonoids and alkaloids that inhibit the intestinal glucose absorption. In addition, AEPn (400 and $500 \mathrm{mg} / \mathrm{kg} \mathrm{BW}$ ) reduced, in dose-dependent manner, the intestinal glucose uptake in rats. The effects of AEPn at $500 \mathrm{mg} / \mathrm{kg}$ BW are similar to those with phlorizin $(0.2 \mathrm{mg} / \mathrm{mL})$, which also significantly reduces intestinal glucose absorption. These results suggest that the aqueous fruit extract of Picralina nitida could contain molecules capable of inhibiting SGLT1, just like the reference substance (phlorizin).
\end{abstract}

Keywords: Picralina nitida; Hypoglycemia; Blood glucose; Glucose uptake

\section{Introduction}

Now a days, diabetes is considered by the WHO as a public health problem. It affects 380 million people worldwide and is the fourth leading cause of hospitalization and the eighth leading cause of death [1]. According to the International Diabetes Federation (IDF), this disease has affected 425 million people worldwide in 2014, with a frequency of 1 death every 6 seconds [IDH (2014). IDH Diabetes Atlas, Sixth edition 2014, www.idf.org/diabetesatlas. Last accessed $20 / 04 / 2016]$. Ivory Coast in 2005 had 67,000 diabetics with a prevalence of $2 \%$ according to WHO [2]. In 2013, there were 490,200 people with diabetes in Côte d'Ivoire with 225,500 undiagnosed cases of diabetes; 1 in 20 adults suffers from this pathology in Ivory Coast [IDH (2013). IDH Diabetes Atlas, Sith edition 2013, www.idf.org/diabetesatlas, last accessed 12/06/2017].

Medical care is very expensive for our low-income populations every year. Therefore, the search for palliative care with the use of pharmacopoeial plants with known or suspected pharmacological effects is important. In the Ivorian

\footnotetext{
${ }^{*}$ Corresponding author

E-mail address: mearsene@gmx.fr

Copyright (C) 2018 Author(s) retain the copyright of this article. This article is published under the terms of the Creative Commons Attribution Liscense 4.0.
} 
pharmacopoeia, the fruits of Picralima nitida (Apocynaceae) are used to treat patients with diabetes [3] with the aim of lowering their blood sugar.

In addition, various parts of the plant have been used in ethno-pharmacopoeia as a remedy against fever, arterial hypertension, jaundice, dysmenorrhea, gastrointestinal disorders and malaria [4]. A phytochemical, toxicological and pharmacological study of the aqueous fruits extract of the plant, on normal and hyperglycemic rats, is carried out in this work.

\section{Material and methods}

\subsection{Biological material}

\subsubsection{Plant material}

The plant material consists of fruits of Picralima nitida of the family Apocynaceae, bought on the market of Port-Bouët (Abidjan, Côte d'Ivoire). This plant has been identified and authenticated at the National Center of Floristry (CNF) of the University Felix Houphouet-Boigny in comparison with the herbarium of this center.

\subsubsection{Animal material}

Rats, Rattus norvegicus (Muridae), of Wistar strain, raised in the same conditions as mice, weighing between 150 and $200 \mathrm{~g}$ of both sexes, were used for pharmacological studies on glycemia and intestinal glucose absorption. The animals benefited from the light of day and the darkness of the night. They were treated according to the standard standards of laboratory animals published by the Interdisplinary Principles and Guidelines for the Use of Animals in Research, Testing and Education issued by the New York Academy of Science Adhoc Committee on Animal Research and the National Institute of Animal Health Hygiene and use of laboratory animals (Ivory Coast).

\subsection{Methods}

\subsubsection{Method of preparation of the aqueous extract of Picralima nitida fruit}

For the preparation of the aqueous fruit extract of Picralima nitida, $200 \mathrm{~g}$ of fruit are cut into pieces and then boiled for 15 minutes in $1 \mathrm{~L}$ of distilled water. The rest of the process is done according to the revised method by authors [5]. After drying, the aqueous fruit extract of Picralima nitida (AEPn) is in powder form. The AEPn powder is weighed, diluted to constitute the different doses that are used for pharmacological studies in rats.

\subsubsection{Demonstration of some secondary metabolites of the aqueous fruit extract of Picralima nitida (Apocynaceae)}

The demonstration of secondary metabolites consists in carrying out characterization tests of the large groups of chemical compounds contained in the aqueous fruit extract of Picralima nitida. The detection of these compounds is based on the principle that they induce chemical reactions in the presence of appropriate reagents [6]. The tests were performed using the analytical techniques described in the authors' work [7-8].

To perform these tests, an AEPn solution is prepared by dissolving $5 \mathrm{~g}$ of the extract in $50 \mathrm{~mL}$ of distilled water. $50 \mathrm{~mL}$ of AEPn solution of concentration $0.1 \mathrm{~g} / \mathrm{mL}$ or $100 \mathrm{mg} / \mathrm{mL}$ are thus obtained.

\subsubsection{Methods of pharmacological studies of glycemia (blood Glucose) in Rats}

The blood glucose is measured using a glucose meter (Accu-Chek® blood glucose meter) with test strips. The principle of this glucometer is that it contains an orifice into which is introduced a test strip for reading the blood glucose. This strip has an absorbent layer on which a drop of blood is deposited. The absorbent layer is finely porous or covered by a membrane on its outer surface that retains the red blood cells and only allows the plasma to diffuse to the lower layers where the reagent is found: glucose-oxidase associated with a chromogen. The resulting color is measured by reflectometry in the blood glucose meter and the blood glucose value is displayed on the meter screen. This value is given in $\mathrm{g} / \mathrm{L}$ and the method is identical to that revised by the authors [8-9].

\subsubsection{Measurement of blood glucose in normoglycemic rats}

The evaluation of the effects of the aqueous extract of Picralima nitida (Apocynaceae) on glycemia in normoglycemic rats is followed in the short term after gavage of animals with different doses of AEPn according to the method revised by authors [8]. This experiment is carried out on twenty Wistar rats of both sexes weighing between 150 and $200 \mathrm{~g}$. The 
animals are divided into 4 lots of 5 rats and fasted for 24 hours. The average blood glucose level of each batch of rats is determined before and after the experiment.

- The rats in batch $1\left(\mathrm{H}_{2} \mathrm{O}\right.$ control) receive $2 \mathrm{~mL}$ of distilled water.

- The rats from batches 2, 3 and 4 (test lots) receive the doses of: 300, 400 and $500 \mathrm{mg} / \mathrm{kg}$ BW, respectively, of the aqueous fruit extract of Picralima nitida.

Glucose levels in these rats are measured just before force-feeding and every 30 minutes during the experiment.

\subsubsection{Measurement of blood glucose levels in hyperglycemic rats}

Measurement of blood glucose in pretreated hyperglycemic rats

Normoglycemic rats are fasted for 24 hours before the experiment. Four (4) lots each containing 5 rats are constituted and the average blood glucose of each lot of rats is determined before experimentation. These batches of rats are distributed as follows:

- Lot $1\left(\mathrm{H}_{2} \mathrm{O}\right.$ control), the rats receive $2 \mathrm{~mL}$ of distilled water and 30 minutes after $2 \mathrm{~mL}$ of distilled water.

- Lot $2(\mathrm{R}-\mathrm{T}+)$ is the positive control. This is the batch containing hyperglycemic control rats. The rats in this batch receive $2 \mathrm{~mL}$ of distilled water and 30 minutes after $2 \mathrm{~mL}$ of anhydrous glucose of concentration $4 \mathrm{~g} / \mathrm{kg} \mathrm{BW}$.

- Lot 3 (R-AEPn), the rats receive $2 \mathrm{~mL}$ of AEPn $500 \mathrm{mg} / \mathrm{kg}$ BW and 30 minutes after $2 \mathrm{~mL}$ of anhydrous glucose (4 $\mathrm{g} / \mathrm{kg} \mathrm{BW})$.

- Lot 4 (R-Glib) consists of the rats which receive $2 \mathrm{~mL}$ of glibenclamide $\left(10^{-2} \mathrm{~g} / \mathrm{kg} \mathrm{BW}\right)$ and 30 minutes after $2 \mathrm{~mL}$ of anhydrous glucose ( $4 \mathrm{~g} / \mathrm{kg} \mathrm{BW})$.

The blood glucose of the rats is measured just before the first gavage $(0 \mathrm{~min})$ and every 30 minutes during the experiment which lasts 180 minutes.

Measurement of blood glucose in post-treated hyperglycemic rats

Rats are fasted for 24 hours before the experiment. Four (4) lots each containing 5 rats are constituted and the average blood glucose of each batch of rats is determined. These batches of rats are distributed as follows:

- Lot 1 (control $\mathrm{H}_{2} \mathrm{O}$ ), where the rats receive $2 \mathrm{~mL}$ of distilled water and 30 minutes after $2 \mathrm{~mL}$ of distilled water.

- Lot $2(\mathrm{R}-\mathrm{T}+)$ is the positive control. The batch of hyperglycemic control rats which receive $2 \mathrm{~mL}$ of anhydrous glucose $4 \mathrm{~g} / \mathrm{kg}$ of BW and 30 minutes after $2 \mathrm{~mL}$ of distilled water.

- Lot 3 (R-AEPn) consists of rats which receive $2 \mathrm{~mL}$ of anhydrous glucose $4 \mathrm{~g} / \mathrm{kg}$ of BW then 30 minutes after $2 \mathrm{~mL}$ of AEPn $500 \mathrm{mg} / \mathrm{kg} \mathrm{BW}$.

- Lot 4 (R-Glib) contains rats which receive $2 \mathrm{~mL}$ of anhydrous glucose $4 \mathrm{~g} / \mathrm{kg}$ PC then 30 minutes after $2 \mathrm{~mL}$ of glibenclamide $\left(10^{-2} \mathrm{~g} / \mathrm{kg} \mathrm{BW}\right)$.

The evaluation of the effects of AEPn on blood glucose levels in these rats is monitored for 180 minutes.

\subsubsection{Study of the intestinal absorption of glucose in the jejunum of rats}

This experiment aims at evaluating the intestinal absorption (by the jejunum) of glucose in the absence (control) and in the presence of AEPn (test).

Intestinal absorption of glucose is measured according to the authors' method [10]. For this study, 5 batches of 5 rats are fasted for 24 hours:

- Lot 1 is the witness;

- Batches 2, 3, 4 are respectively treated with 300, 400, $500 \mathrm{mg} / \mathrm{kg} \mathrm{BW}$ of AEPn.

- Lot 5 is treated with phloridzine $(0.2 \mathrm{mg} / \mathrm{mL})$.

Intraperitoneally, the rats are anesthetized with Lignocaine ${ }^{\circledR}$ (Xylocaine) at a dose of $2.5 \mathrm{~mL} / \mathrm{kg}$ BW. After anesthesia, their abdomen is open and the jejunum is ligated on one end. On the other end, $0.5 \mathrm{~mL}$ of anhydrous glucose (4 g / L) is introduced into the control rats (batch 1) and $0.5 \mathrm{~mL}$ of distilled water. The rats from batches $2,3,4$ receive $0.5 \mathrm{~mL}$ of AEPn at the respective doses of 300, 400, $500 \mathrm{mg} / \mathrm{kg}$ of Bw and $0.5 \mathrm{~mL}$ of anhydrous glucose (4 g / L). The rats in batch 
5 receive $0.5 \mathrm{~mL}$ of phloridzine and then $0.5 \mathrm{~mL}$ of anhydrous glucose $(4 \mathrm{~g} / \mathrm{L})$. The jejunum of the animals is ligated at both ends over a length of 6 centimeters and the abdomen is closed by stitches. After 60 minutes of experimentation, the ends of the jejunum are isolated and the residual glucose concentration is assayed by the GOD-POD method [11] using a Biolabo spectrophotometer (France). The absorbed fraction is the fraction that has disappeared from the intestinal lumen after 60 minutes of experimentation. The absorbed glucose level is calculated as follows:

$$
\text { Glucose uptake }(\%)=\frac{C_{\text {glucose }(T 0)}-C_{\text {glucose }(T 1)}}{C_{\text {glucose }(T 0)}}
$$

$\mathrm{C}_{\text {glucose }}=$ glucose concentration

T0 = beginning of experimentation, introduction of substances into the jejunum

$\mathrm{T} 1$ = end of the experiment, jejunum isolation after 1 hour

\subsection{Pharmacological substances and physiological solutions}

The substances and solutions used in these pharmacological tests are listed as follows:

- Glibenclamide (DAONIL), a sulphonylurea, as a reference substance for pharmacological tests on blood glucose; from Sanofi-Aventis France laboratories.

- Phloridzine (or phlorizine) dihydrate, from Carl Roth GmbH + KG-Karlsruhe, Germany.

- Sodium chloride at $9 \%$ ( $\mathrm{NaCl} 9 \%)$.

- Cooper's anhydrous glucose solution (4 g/L) ; Cooper France laboratory.

- Lignocaine ${ }^{\circledR}$ (Xylocaine) from Aspen Pharma Trading Ltd., Republic of South Africa.

\subsection{Statistical analysis}

The GraphPad InStat 5 computer program (San Diego CA, USA) is used for statistical analysis of results. The values are expressed as an average followed by the standard error on the mean ( $\pm \pm E S M)$. The difference between two values is determined by the Student-Newman-Keuls comparison test. For $* \mathrm{P}<0.05$ the observed difference is significant, $* * \mathrm{P}<$ 0.01 very significant, ${ }^{* * *} \mathrm{P}<0.001$ Hight significant. GraphPad prism 5 (San Diego Ca, USA) is used to plot the graphs.

\section{Results and discussion}

\subsection{Phytochemical screening of the aqueous fruit extract of Picralima nitida}

Phytochemical screening revealed several groups of chemical compounds contained in the aqueous fruit extract of Picralima nitida. Tube tests reveal the presence of alkaloids, sterols, polyterpenes, flavonoids, saponosides, tannins and polyphenols. Of the secondary metabolites sought, only the quinone compounds were not detected in this extract. Table 1 summarizes the results of this phytochemical study.

Table 1 Phytochemical screening result of the aqueous fruit extract of Picralima nitida

\begin{tabular}{lll}
\hline Test compounds & Test or reagents & Result \\
\hline Steroids and polyterpenes & Liebermann & + \\
Polyphenols & Ferric Chloride & + \\
Flavonoids & Cyanidin & + \\
Saponosides & vigorous agitation & + \\
Quinone compounds & Borntraegen & - \\
Alkaloids & Dragendorff & + \\
& Bouchardat & + \\
Tannins & Stiasny & + \\
& Hydrochloric acid & + \\
\hline
\end{tabular}

(+): Presence of the compound

$(-)$ : Absence of the compound 


\subsection{Pharmacological effects of the aqueous fruit extract of Picralima nitida on glycemia}

\subsubsection{Dose response effects of AEPn on glycemia in normoglycemic rats}

The effects of oral administration of the aqueous fruit extract of Picralima nitida (AEPn) at the respective doses of 300 , 400 and $500 \mathrm{mg} / \mathrm{kg} \mathrm{BW}$ on the blood glucose levels of normoglycemic rats are shown in Figure 1. The baseline blood glucose values of the rats are identical $0.91 \pm 0.01 \mathrm{~g} / \mathrm{L}$ in all batches before the different treatments. In control rats receiving only distilled water, the blood glucose level did not vary significantly $(\mathrm{P}>0.05)$ for the duration of this experiment. It is of the order of $0.91 \pm 0.03 \mathrm{~g} / \mathrm{L}$. AEPn at a dose of $300 \mathrm{mg} / \mathrm{kg} \mathrm{BW}$ did not result in a significant (ns; P> 0.05 ) decrease in blood glucose levels in treated rats, ranging from $0.91 \pm 0.01 \mathrm{~g} / \mathrm{L}$ to $0.86 \pm 0.05 \mathrm{~g} / \mathrm{L}$ is a decrease of $5.49 \%$. In contrast, AEPn at doses of 400 and $500 \mathrm{mg} / \mathrm{kg} \mathrm{BW}$ produced significant and dose-dependent decreases in blood glucose levels in treated rats. These hypoglycaemia increase with time. Thus AEPn at the dose of $400 \mathrm{mg} / \mathrm{kg}$ BW lowered blood glucose significantly $\left({ }^{*} \mathrm{P}<0.05\right)$ after 1 hour. Two hours after the administration of AEPn at this dose, the blood glucose which was initially of $0.91 \mathrm{~g} / \mathrm{L} \pm 0.01 \mathrm{~g} / \mathrm{L}$ passes to $0.79 \pm 0.01 \mathrm{~g} / \mathrm{L}$; a decrease of $13.18 \%(* * \mathrm{P}<0.01$ ). The $500 \mathrm{mg} / \mathrm{kg} \mathrm{BW}$ AEPn dose results in a greater decrease in blood glucose. From $0.91 \pm 0.01 \mathrm{~g} / \mathrm{L}$ initially, the blood glucose rose to $0.71 \pm 0.06 \mathrm{~g} / \mathrm{L}$ after 2 hours; a reduction of $21.97 \%(\mathrm{P}<0.01)$.

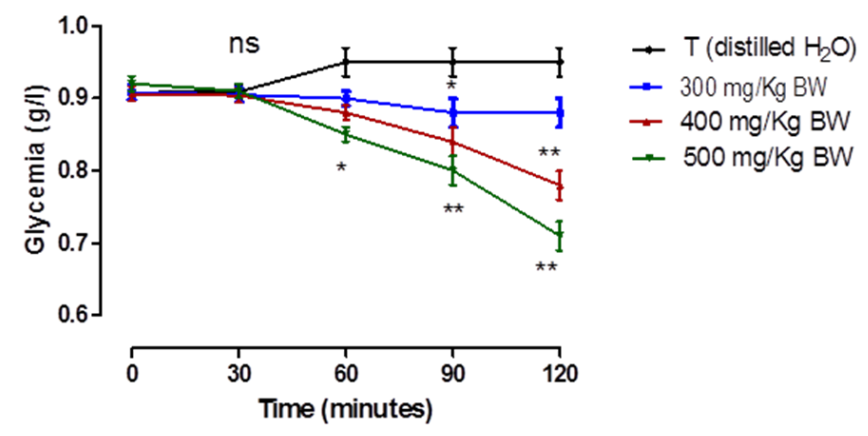

Figure 1 Dose-response effects of an aqueous fruit extract of Picralima nitida (Apocynaceae) on glycemia of normoglycemic rats. (ns: non-significant; ${ }^{*} \mathrm{p}<0.05$ significant; ${ }^{*} \mathrm{p}<0.01$ very significant)

\subsubsection{Effects of AEPn and glibenclamide on blood glucose levels in hyperglycemic rats}

Variation in blood glucose levels of pretreated hyperglycemic rats

In this series of experiments the rats are first treated with AEPn at $500 \mathrm{mg} / \mathrm{kg}$ BWor with glibenclamide at $10^{-2} \mathrm{~g} / \mathrm{kg}$ BW. The basal blood glucose level of these rats at the beginning of the experiment did not vary significantly between the different batches and was $0.86 \pm 0.01 \mathrm{~g} / \mathrm{L}$. Control group (R-T) rats receive only distilled water. In these control group (R-T) rats that are not treated, the blood glucose is stationary during the experiment.

Animals in the positive control group ( $\mathrm{R}-\mathrm{T}+$ ) receive distilled water and then 30 minutes after the anhydrous glucose. Their blood glucose level increases 30 minutes after the consumption of anhydrous glucose and decreases slowly during the experiment. In these hyperglycemic or positive control (R-T +) control rats, the blood glucose level increases from $0.86 \pm 0.01$ to $1.50 \pm 0.02 \mathrm{~g} / \mathrm{L}$; an increase of $0.64 \pm 0.07 \mathrm{~g} / \mathrm{L}$. This equates to an increase of $74.41 \%$, then gradually decreases to reach the original level (basal level).

In rats that were pretreated with AEPn at $500 \mathrm{mg} / \mathrm{kg} \mathrm{BW}$ (R-AEPn) blood glucose increased from $0.86 \pm 0.01$ to 1.31 $\mathrm{g} / \mathrm{L}$; an increase of $0.45 \pm 0.04 \mathrm{~g} / \mathrm{L}$. This equates to a rate of $52.32 \%$. In rats treated with glibenclamide at $10^{-2} \mathrm{~g} / \mathrm{kg} \mathrm{BW}$ (R-Glib), the blood glucose level increased from $0.86 \pm 0.01 \mathrm{~g} / \mathrm{L}$ to $1.22 \pm 0.03 \mathrm{~g} / \mathrm{L}$, an increase of $0.36 \pm 0.06 \mathrm{~g} / \mathrm{L}$. This equates to a rate of $41.86 \%$. Figure 2 shows the changes in blood glucose during this experiment. In glucose-fed rats, after hyperglycemic peaks, blood glucose gradually decreases, and the time to return to the initial blood glucose level varies according to the pre-administered substances. In positive control animals that received only glucose (R-T +), the basal glucose level was found 150 minutes after glucose administration.

In contrast, in rats pretreated with AEPn (R-AEPn) or with glibenclamide (R-Glib), the basal glucose level was found after 120 minutes and 90 minutes, respectively. Then hypoglycaemia of $0.71 \pm 0.02 \mathrm{~g} / \mathrm{L}(-0.15 \pm 0.02 \mathrm{~g} / \mathrm{L})$ and 0.56 $\mathrm{g} 7 \mathrm{~L}(-0.30 \pm 0.05 \mathrm{~g} / \mathrm{L})$ after 180 minutes is obseved. The equivalent of $17.44 \%$ and $34.88 \%$ hypoglycemia respectively is obtained after 180 minute. This hypoglycemia is very significant $\left({ }^{* *} \mathrm{P}<0.01\right)$ 


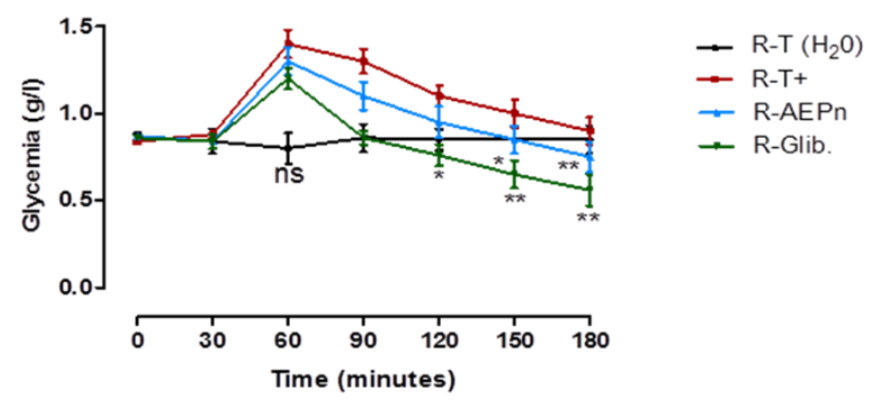

Figure 2 Time-dependent change in blood glucose levels in hyperglycemic rats pretreated with AEPn or glibenclamide

$\mathrm{R}-\mathrm{T}$ : control rats receiving distilled water

$\mathrm{R}-\mathrm{T}+$ : Positive (hyperglycemic) control rats given glucose

R-AEPn: rats receiving AEPn (500 mg/kg BW), then glucose

R-Glib: rats given glibenclamide $\left(10^{-2} \mathrm{~g} / \mathrm{kg} \mathrm{BW}\right)$, then glucose

ns: non-significant; ${ }^{*} \mathrm{p}<0.05$ significant; ${ }^{* *} \mathrm{p}<0.01$ very significant.

\section{Variation in blood glucose levels in post-treated hyperglycemic rats}

The rats from the test batches in this experiment first receive anhydrous glucose followed 30 minutes after by AEPn at $500 \mathrm{mg} / \mathrm{kg} \mathrm{BW}$ or glibenclamide at $10^{-2} \mathrm{~g} / \mathrm{kg}$ BW. In control rats (R-T) receiving only distilled water, blood glucose remains stationary during the experiment (no significant variation; ns). In hyperglycemic (R-T +) control rats receiving anhydrous glucose and then water, 30 minutes after glucose administration, a hyperglycemia peak is recorded. Then the hyperglycemia decreases progressivly at the basal level.

Administration of glucose to rats in the positive control group (R-T +) and test lots (R-AEPn and R-Glib) revealed peaks of hyperglycemia 30 minutes later. The blood glucose levels of the animals increased from $0.86 \pm 0.01 \mathrm{~g} / \mathrm{L}$ to $1.49 \pm 0.03$ $\mathrm{g} / \mathrm{L}$; an increase of $0.63 \pm 0.03 \mathrm{~g} / \mathrm{L}$. which is the equivalent of $73.25 \%$ hyperglycemia recorded. Subsequently, these hyperglycemias gradually decrease until the return to basal blood glucose baseline values. These decreases in glucoseinduced hyperglycemia and the time to baseline glucose levels are variable depending on the substance administered. Figure 3 shows the change in glycemia of post-treated rats. In positive control animals the return to basal level glucose occurs after 150 minutes of experimentation. In contrast, in rats that are post-treated with AEPn $500 \mathrm{mg} / \mathrm{kg}$ BW or glibenclamide $10^{-2} \mathrm{~g} / \mathrm{kg} \mathrm{BW}$, the return to baseline glucose occurs respectively 120 minutes and 90 minutes after administration of the glucose. Then, a slight hypoglycemia of $0.68 \pm 0.02 \mathrm{~g} / \mathrm{L}(-0.18 \pm 0.01 \mathrm{~g} / \mathrm{l})$ followed in rats treated with glibenclamide. A significant decrease of $20.93 \%\left({ }^{* *} \mathrm{P}<0.01\right)$. In rats treated with AEPn the recorded hypoglycemia is not significant. It is $0.78 \mathrm{~g} / \mathrm{L}$; a decrease of $09.30 \%\left({ }^{*} \mathrm{P}<0.05\right)$.

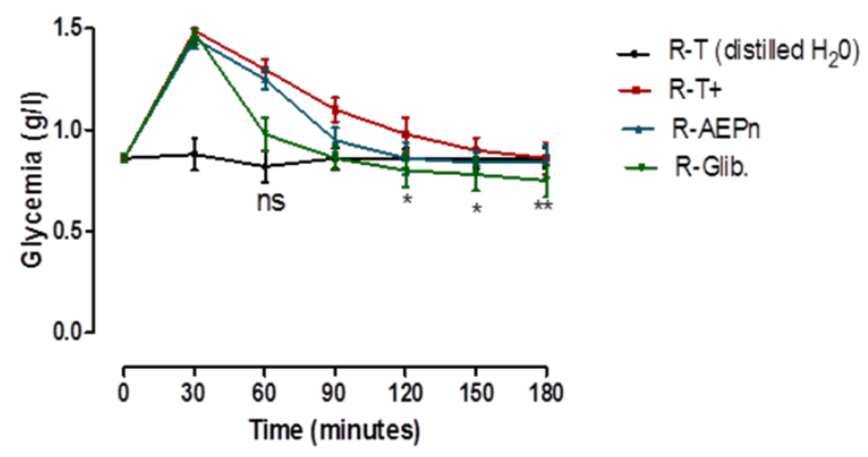

Figure 3 Time-dependent change in blood glucose levels in hyperglycemic rats post-treated with AEPn or glibenclamide (ns: non-significant; ${ }^{*} \mathrm{p}<0.05$ significant and ${ }^{* *} \mathrm{p}<0.01$ very significant)

$\mathrm{R}-\mathrm{T}+$ : positive (hyperglycemic) control rats given glucose (4 g / $\mathrm{kg} \mathrm{BW}$ )

R-EAPn: rats given glucose (4 g / kg BW), then AEPn (500 mg / kg BW)

$\mathrm{R}-\mathrm{Glib}$ : rats given glucose $(4 \mathrm{~g} / \mathrm{kg} \mathrm{BW})$, then glibenclamide $\left(10^{-2} \mathrm{~g} / \mathrm{kg} \mathrm{BW}\right)$ 


\subsection{Effects of AEPn and phloridzin on intestinal glucose uptake at the jejunum level of rats}

During this experiment, the glucose concentration introduced into the jejunum (gut fragment) of the rats is $4 \mathrm{~g} / \mathrm{L}$. Residual glucose in control guts fragments and test fragments is determined at the end of the experiment. Figure 4 shows intestinal glucose absorption percentages in rats treated with AEPn and Phloridzin for one hour. In the control gut fragments, the residual glucose concentration is $1.67 \mathrm{~g} / \mathrm{L}$. At the end of the experiment (1 hour), a glucose absorption rate of $58.2 \%$ is determined. In guts that are treated with AEPn at doses of $300 \mathrm{mg} / \mathrm{kg} \mathrm{BW}, 400 \mathrm{mg} / \mathrm{kg}$ BW and $500 \mathrm{mg} / \mathrm{kg} \mathrm{BW}$, residual glucose concentrations are $1.81 \mathrm{~g} / \mathrm{L}, 2.17 \mathrm{~g} / \mathrm{L}$ and $2.37 \mathrm{~g} / \mathrm{L}$, respectively at the end of the experiment. Glucose absorption percentages are $54.63 \%, 47.73 \%$ and $40.59 \%$ respectively (significant, ${ }^{*} \mathrm{P}<0.05$ and very significant, ${ }^{* *} \mathrm{P}<0.01$ decrease). Intestinal glucose absorption is therefore reduced in the presence of AEPn compared to the control. This reduction in intestinal glucose uptake in the presence of AEPn is dose dependent. Similarly, in the rats treated with Phloridzin $(0.20 \mathrm{mg} / \mathrm{mL}$ ) intestinal glucose absorption is $35 \%$ (hight significant, $\left.{ }^{* * *} \mathrm{P}<0.001\right)$

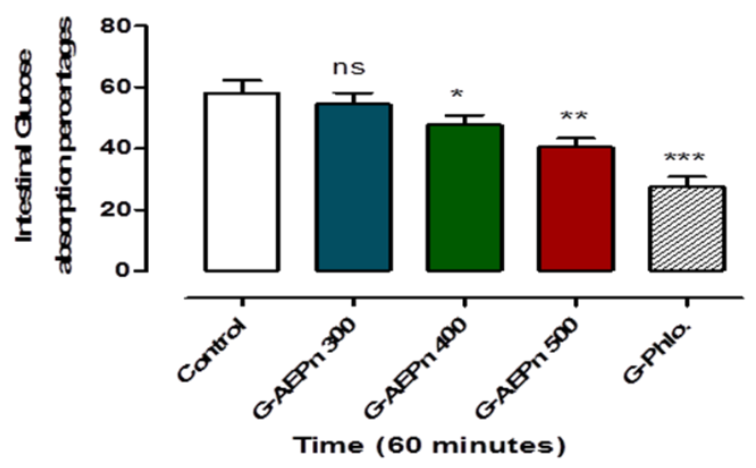

Figure 4 Absorption of intestinal glucose for one hour of rats having received AEPn and Phloridzin. (ns: nonsignificant; ${ }^{*} \mathrm{P}<0.05$ significant; ${ }^{* *} \mathrm{P}<0.01$ very significant; ${ }^{* * *} \mathrm{P}<0.001$ high significant).

\section{Discussion}

Phytochemical screening shows that AEPn contains alkaloids, sterols, polyterpenes, flavonoids, saponosides, tannins and polyphenols. These secondary metabolites are believed to be responsible for the potential pharmacological effects of the aqueous fruit extract of Picralima nitida (Apocynaceae). Indeed, Belobrajdic and Bird [12] reported that green tea polyphenols and soy isoflavone inhibit the intestinal absorption of glucose. Kim's work [13] has demonstrated the inhibition of $\alpha$-glucosidase by alkaloids. Ladouri [14] has shown that the high content of flavonoids and phenolic compounds in the aqueous extract of Zygophyllum album (Zygophylaceae) would help to reduce diabetic hyperglycemia.

The study of the pharmacological effects of AEPn on blood glucose shows that fasting blood glucose (basal blood glucose) values in Wistar rats used range from $0.60 \pm 0.03 \mathrm{~g} / \mathrm{L}$ to $0.93 \pm 0.04 \mathrm{~g} / \mathrm{L}$. These values are consistent with those of normoglycemic Wistar rats, reported by authors $[8,15]$. These authors reported that basal glycaemia values in normoglycemic Wistar rats ranged from $0.38 \pm 0.01 \mathrm{~g} / \mathrm{L}$ to $1.2 \pm 0.05 \mathrm{~g} / \mathrm{L}$ to $0.59 \pm 0.02 \mathrm{~g} / \mathrm{L}$ and $1.2 \pm 0.05 \mathrm{~g} / \mathrm{L}$ respectively. These results clearly show that the Wistar rats used in our study are normoglycemic.

Administration by gavage of anhydrous glucose $4 \mathrm{~g} / \mathrm{kg}$ BW to rats causes hyperglycemia (glycemia $\geq 1.5 \pm 0.05 \mathrm{~g} / \mathrm{L}$ ) which occurs after 30 minutes. This induced hyperglycemia is significantly reduced $(\mathrm{P}<0.01)$ by AEPn in pretreated and post-treated rats. The AEPn reduction at $500 \mathrm{mg} / \mathrm{kg} \mathrm{BW}$ of the glucose-induced hyperglycemia $4 \mathrm{~g} / \mathrm{kg} \mathrm{BW}$ is identical to that of glibenclamide at $10^{-2} \mathrm{~g} / \mathrm{kg} \mathrm{BW}\left({ }^{* *} \mathrm{P}>0.01\right)$. Thus, like glibenclamide, AEPn has antihyperglycaemic effects. The antihyperglycemic and hypoglycaemic properties of AEPn are similar to those of many medicinal plants from the traditional African pharmacopoeia. This is the case of Colocynthis vulgaris (Cucurbitaceae) [16], Allium sativum (Liliaceae), Citrullus colocynthis (Cucurbitaceae) [17] and Pseudarthria hookeri (Fabaceae) [15].

The similar effects of AEPn with those of glibenclamide on blood glucose suggest that AEPn and glibenclamide may act by similar mechanisms. Indeed, it has been reported that sulfonylureas induce hypoglycaemic, antihyperglycaemic effects in rats by stimulating insulin production by pancreatic beta cells, thus promoting the storage of glycogen in the liver [18]. The hypoglycemic and antihyperglycaemic effects of AEPn, observed in vivo, can be attributed to the presence in this extract of polyphenols, flavonoids and alkaloids that inhibit the intestinal absorption of glucose $[15,16,17]$. 
In addition, AEPn (400 and $500 \mathrm{mg} / \mathrm{kg}$ BW) reduced, in a dose-dependent manner, the intestinal glucose uptake in rats. The effects of AEPn at $500 \mathrm{mg} / \mathrm{kg}$ BW are similar to those with phloridzin $(0.2 \mathrm{mg} / \mathrm{mL})$, which also significantly reduces intestinal glucose absorption. Phloridzin is a (competitive) inhibitor of D-glucose on SGLT (Sodium Glucose Transporter) transporters. As a result, it inhibits glucose uptake in the intestinal lumen [19]. The absorption of glucose in the intestine is under the action of two transporters, the co-transporter of sodium-dependent D-glucose (SGLT1), which is found in the brush border of the enterocytes, and the transporter of the sodium independent glucose (GLUT2) found in the basolateral membrane [20]. SGLT1 is probably the main importer of glucose in the intestine when luminal concentrations are low [21]. However, in case of increased glucose in the lumen, SGLT1 facilitates the insertion of GLUT2 on the apical membrane of the enterocyte to facilitate glucose uptake [24]. These results suggest that the aqueous fruit extract of Picralima nitida could contain molecules capable of inhibiting SGLT1, just like the reference substance (phloridzin).

\section{Conclusion}

The aqueous fruit extract of Picralima nitida (Apocynaceae) contains hypoglycemic and antihyperglycemic substances such as glibenclamide and its mechanism could be mediated through inhibition of SGLT1-dependent D-glucose uptake such as phloridzin. This justifies its use in traditional pharmacopoeia.

\section{Compliance with ethical standards}

\section{Acknowledgments}

This research work was carried out at the animal physiology laboratory of UFR Biosciences. We have received no external input that deserves our thanks or acknowledgment.

\section{Disclosure of conflict of interest}

The authors declare no conflict of interest.

\section{Statement of ethical approval}

Animals were treated according to the standard standards of laboratory animals published by the Interdisplinary Principles and Guidelines for the Use of Animals in Research, Testing and Education issued by the New York Academy of Science Adhoc Committee on Animal Research and the National Institute of Animal Health Hygiene and use of laboratory animals (Ivory Coast).

\section{References}

[1] WHO (2014). Global statut of transmissible diseases report in 2014. Geneva, 6-7.

[2] WHO (2013). Preventing Chronic Diseases: A Vital Investment. WHO report, 54-55.

[3] Cui XL, Ananian C, Perez E, Strenger A, Beuve AV and Ferraris RP. (2004). Cyclic AMP stimulates fructose transport in neonatal rat small intestine. The Journal of Nutrition, 134 (7), 1697-1703.

[4] Erharuyi O, Falodun A and Langer P. (2014) Medicinal uses, phytochemistry and pharmacology of Picralima nitida (Apocynaceae) in tropical diseases: A review. Asian Pacific Journal of Tropical Medicine, 7(1), 1-8.

[5] Mea A, Abo KJC, Kassi YT and Irie Bi JS. (2016). The effect of an aqueous extract of Bark of Anacardium occidental L. (Anacardiaceae) on arterial pressure and respiratory movments in the rabbit. International Journal of Current Research, 8(12), 42727-42733.

[6] Wagner H and Bladt S. (2001). Plant drug analysis. A thin layer chromatography atlas. $2^{\text {nd }}$ edition, springer, Berlin, (Deuchland), 3-51.

[7] Schersten B, Kuhl C, Hollender A and Ekman R. (2014). Blood glucose measurement with dextrostix and new reflectance meter. British Medical Journal, 3(5927), 384-387.

[8] Mea A, Ekissi YHR, Abo KJC and Kahou Bi GP. (2017) Hypogglycaemiant and antihyperglycaemiant effect of Justicia secunda M. Vahl (Acanthaceae) on Glycaemia in the wistar rat. International Journal of Development Research. 07(06), 13178-13184. 
[9] Mansar-Benhamza L, Djerrou Z and Hamdi P. (2013). Evaluation of antihyperglycemic and side effect of Erythreae centaurin L. Pers. in rats. African Journal of Biotechnology, 12(05), 6980-6985.

[10] Gonzalez-Mujica F, Motta N, Marquez AH and Capote-Zulueta J. (2003). Effects of Bauhinia megalandra aqueous leaf extract on intestinal glucose absorption and uptake by enterocyte brusch border membrane vesicles. Fitoterapia, 74, 84-90.

[11] Arti P, Shreevastava N, Arun P and Neupane D. (2015). Experiment-09 Estimation of Blood Glucose by GOD-POD Method. In book: Biochemistry Laboratory Manual, 49-52.

[12] Belobrajdic DP and Bird AR. (2013). Potential role of phytochemicals in whole grains for the prevention of type 2 diabetes. Nutrition journal, 12(1), 62.

[13] Kim HS, Kim YH, Hong YS, Paek NS, Lee HS, Kim TM, Kim KW, Lee JJ. (1999). $\alpha$-glucosidase inhibitor from Commelina communis. Planta medica, 65(05), 437-439.

[14] Suleiman MM, Dzenda T and Sani CA. (2012). Antidiarrhoeal activity of the methanol stem-bark extract of Annona senegalensis Pers. (Annonaceae). Journal of Ethnopharmacology, 116(1), 125-130.

[15] Kahou BGP, Abo KJC, Mea A, Irie BJS and Karou TG. (2016). Antidiabetic and hypolipemic effects of total aqueous extract of Pseudarthria hookeri Wight \& Arn. (Fabaceae) on hemoglobin glycation in alloxan induced diabetic rats. International journal of pharmacy \& pharmaceutical research. Human Journals, 7(4), 146-156.

[16] Sakine MA, Mahmout Y, Gbenou J, Agbodjogbe W and Moudachirou M. (2011). Effet antihyperglycémiant des extraits de Boscia senegalensis (Pers.) Lam. Ex Poiret et de (Colocynthis vulgaris L.) Schrad. Phytothérapie, 9(5), 268-273.

[17] Patel DK, Prasad SK, Kumar R and Hemalatha S. (2012). An overview on antidiabetic medicinal plants having insulin mimetic property. Asian Pacific Journal of Tropical Biomedicine, 2(4), 320-330.

[18] Doyle ME and Egan JM. (2003). Pharmacological agents that directly modulate insulin secretion. Pharmacological Reviews, 55(1), 105-131

[19] Rossetti L, Smith D, Shulman GI, Papachristou D and DeFronzo RA. (1987). Correction of hyperglycemia with phlorizin normalizes tissue sensitivity to insulin in diabetic rats. J Clin Invest., 79(5), 1510-1515.

[20] Khan J, Wingertzahn M, Harper R and Wapnir R. (1999). Development of the intestinal SGLT-1 in the rat. Pediatric Research, 45-54.

[21] Raybould H, Glatzle J, Freeman S, Whited K, Darcel N, Liou A and Bohan D. (2006). Detection of macronutrients in the intestinal wall. Autonomic Neuroscience: Basic and Clinic, 125, 28-33.

[22] Kellet GL and BRot-Laroche E. (2008). Sugar absorption in the intestine: the role of GLUT 2. Annu. Rev. Nutr., 28, 35-54.

\section{How to cite this article}

Placide EA, Arsene M, Parfait KBG, Jean Severin IB, Joseph NK and Jean Claude AK. (2018). Effect of Picralina nitida on the glycemia and intestinal absorption of glucose in rat. GSC Biological and Pharmaceutical Sciences, 5(3), 106-114. 